УДК [37-069](477)

DOI: https://doi.org/10.35387/od.2(16).2019.49-56

Філіпчук Наталія Олександрівна - кандидат педагогічних наук, старший науковий співробітник, докторант Інституту педагогічної освіти і освіти дорослих імені Івана Зязюна НАПН України

ORCID ID: https://orcid.org/0000-0002-1023-923X

E-mail:vpee2011@ukr.net

\title{
ПРІОРИТЕТИ РОЗВИТКУ СУЧАСНОЇ МУЗЕЙНОЇ ПЕДАГОГІКИ В УКРАЇНІ У КОНТЕКСТІ ОСВІТИ ВПРОДОВЖ ЖИТТЯ
}

\begin{abstract}
Анотація. Зазначено, що сучасний музейний простір, що вибудований на основі принципів науковості, історизму, культуровідповідності, значно розширюе пізнавальні можливості навчальних освітніх програм різного рівня, спрямованих на отримання нових знань, на формування особистості, здатної до критичного мислення, з активною громадянською позицією. Наголошено на важливості ролі музейних закладів, покликаних сприяти розв'язанню стратегічного завдання - творення української національної ідентичності. Наголошено, що музейні матеріали для педагога, учня, студента містять широку палітру культурно-історичних, моральноетичних, духовних, соціально-політичних, естетичних цінностей, ідей, поглядів, що акумулюються в життєтворчості видатних українців, представлених багатьма генераціями національних діячів у сферах науки, мистецтва, політики і державного будівництва, літератури. З'ясовано, що сучасна політична, соціальна, духовна, безпекова ситуація актуалізує впровадження цінностей української ідентичності, єдиної ідеологічної концепції утвердження національної ідеї. До таких дій спонукає необхідність реалізації положень багатьох нормативних, законодавчих документів. Сучасні музеї повинні мати спільну фрілософрію діяльності - виховання громадянськості й патріотизму, фоормування національної свідомості, державної $i$ особистої гідності, пізнання культурної спадщини, надбань науки, розвиток критичного мислення, творчих здібностей, громадянської активної позиції. Обгрунтовано, що узейна педагогіка має оптимальні можливості для формування у молоді таких необхідних якостей, як критичність, активність, креативність.

Ключові слова: музейна педагогіка, музей, національна ідея, національна ідентичність, громадянськість, сучасний музейний простір, пріоритети музейної педагогіки.
\end{abstract}

Filipchuk Natalia - candidate of pedagogical sciences, senior researcher, doctoral student of Ivan Ziaziun Institute of Pedagogical and Adult Education of the NAES of Ukraine

ORCID ID: https://orcid.org/0000-0002-1023-923X

E-mail:vpee2011@ukr.net 


\title{
PRIORITIES OF THE DEVELOPMENT OF MODERN MUSEUM PEDAGOGY IN UKRAINE IN THE CONTEXT OF LIFELONG EDUCATION
}

\begin{abstract}
There has been determined that the modern museum space, built on the scientific principles, historicism, cultural correspondence, significantly expands the cognitive possibilities of various levels educational programs, aimed at acquiring new knowledge, forming a person capable to critical thinking, with an active civic position. It is proved that nowadays museum institutions play a special role in realizing the strategic task of creating Ukrainian national identity. Accordingly, the museum materials for a teacher, pupil, student contain a wide range of cultural, historical, moral, ethical, spiritual, socio-political, aesthetic values, ideas, views that are accumulated in the life creation of outstanding Ukrainians, represented by many generations of national figures in the fields of science, politics and state-building, literature. It was found that the current political, social, spiritual, security, international situation leads to the introduction of values of Ukrainian identity, to assert a common ideological concept of the national idea. Such approaches prompt the need to implement the provisions of many regulatory and legislative documents. Modern museums should have a common philosophy of activity education of citizenship and patriotism, formation of national consciousness, state and personal dignity, knowledge of cultural heritage, heritage of science, development of critical thinking, creative abilities and active civic participation. Museum pedagogy has the optimal opportunities for formation among young people such necessary qualities as criticality, activity, creativity, taking into account personal-emotional perception.
\end{abstract}

Key words: museum pedagogy, museum, national idea, national identity, citizenship, modern museum space, priorities of museum pedagogy.

Постановка проблеми, їі актуальність. Стале соціокультурне середовище $\epsilon$ вічно затребуваним імперативом, оскільки від нього залежить не лише успіх у навчально-виховній діяльності, але й суспільнодержавний прогрес. Між школою, іншими освітніми інститутами й соціокультурним середовищем має відбуватися взаємозв'язок, діалог, взаємозбагачення, долаючи замкненість, локальну фрункціональність. Освітне середовище ніяким чином не може обмежуватися лише окресленими формально-відомчими межами. Для успішного формування ключових компетентностей людини, адекватних вимогам часу, необхідно розширювати освітній простір шляхом залучення до нього як формальних, так і неформальних суспільних одиниць. Синергія зусиль, інтеграція освітніх і культурних інституцій уможливлює творення більш сприятливих умов для інтелектуального, гуманного, духовного, громадянського розвитку особистості, удосконалюючи засоби, технології, зміст і методику навчально-виховного процесу. Тому виховна, дидактична, інформаційно- 
пізнавальна, професійна функції отримують нові можливості завдяки розширенню й удосконаленню освітнього середовище. Отже, вихід закладів освіти поза власні межі - у музеї, театри, фрілармонії, бібліотеки, творчі майстерні, наукові лабораторії, мистецькі заклади і колективи та до інших креативно-творчих інституцій, є актуальним, затребуваним процесом.

Подібні підходи, згідно з якими доступ до культури стає стрижневим напрямом і визначальним пріоритетом для провідних освітніх систем, мають активно впроваджуватися в сучасну українську освітню модель. Музейна та освітня політика не просто утримують і культивують, об'єднавши зусилля, таке значимо-суспільне явище, як музейна педагогіка, вони здатні і зобов'язані виробляти нові стратегії пізнання світу (передусім національного (!)), більш ефективні навчально-виховні технології, удосконалюючи методики формування й розвитку історичної, естетичної, морально-етичної культури дітей, молоді та дорослих.

В умовах сьогодення особливо важливого значення набуває необхідність об'єднання потенціалів закладів освіти і музейних установ для інтелектуального гуманного, громадянського й професійного розвитку Людини. Ця інтеграційна модель, що передусім асоціюється з сутністю музейної педагогіки, посідатиме дедалі більш вагоме місце в освітньокультурній ніші суспільства. Адже, з одного боку, через матеріальнотехнічну неспроможність, лише 1/10 частина музейних експонатів на даний час $є$ доступними для відвідувачів. Решта, абсолютна більшість музейних предметів з Державного музейного фонду, перебувають поза увагою i можливістю їх публічного сприйняття. 3 іншого боку - історія і культура українського народу, які впродовж століть зазнавали жорстоких утисків, переслідувань, фальшування, брехні й замовчування, потребують більш інтенсивного процесу самопізнання постколоніальної і пост-геноцидної нації.

Аналіз останніх досліджень і публікацій. У сучасних публікаціях науковці висвітлюють різноаспектний потенціал музейних інституцій в історичній ретроспективі (Валенкевич, 2015; Гайда, 2016; Цибко, 2011 та ін.); можливості використання засобів музейної педагогіки у розвитку особистості (Грищенко, 2016; Дробна, 2011; Черничко, 2014 та ін.). Окремі праці присячено висвітленню специфіки музейної андрагогіки (Аніщенко, Іванова, Прийма, 2017; Куцаєва Т.; Матвійчук О. та ін.). Водночас можна констатувати фррагментарність досліджень щодо пріоритетів розвитку музейної педагогіки з урахуванням сучасних реформаційних змін в освіті, що зумовило вибір теми публікації.

Мета статті - виявити та узагальнити пріоритети розвитку музейної педагогіки в Україні в сучасних соціокультурних умовах на основі використання методів теоретичного аналізу і узагальнення.

Виклад основного матеріалу дослідження. Соціальні умови, суспільно-державні затребуваності, особистісні вмотивованості будуть формувати запит, коли музейна педагогіка дедалі більше зміцнюватиме свої позиції серед гуманітарних субдисциплін, роблячи навчально- 
виховний процес змістовнішим, емоційно привабливішим. П̈ї функції $\mathrm{i}$ дидактичні можливості добре вписуються в норми сучасних європейських еталонних рамок компетентностей. Важко уявляються в європейському освітньому просторі процеси формування культурних, соціальних і громадянських компетентностей без активного, науково й дидактично обґрунтованого використання музейних ресурсів. Адже навіть досконало написані підручники, розроблені сучасні навчальні програми не завжди містять необхідний матеріал та інформацію.

Зазначимо, що потенціал різнопрофрільних і багатотематичних музеїв уможливлює досягнення значно кращого результату при вивченні та засвоєнні тем від природничого, технократичного напрямів до історичнокультурного, літературного, мистецького. Суто суб'єктивна проблема полягає в тому, що, по-перше, варто переконати громадську і професійну (педагогічну) спільноту про значний раціональний та ірраціональний потенціал музейництва, який би став ефективним засобом на шляху (затребуваного часом) сучасних реформацій у сфрері освіти. Тому, згідно європейських і світових практик, музей перетворився на таку прикладну інституцію, коли відвідувачі (учень, студент, учитель, викладач, науковець) отримують ґрунтовні знання шляхом «занурення» у розмаїття тем - від глобалізму, світових катаклізмів, фундаментальних досягнень Людського розуму і талантів, епохальних явищ історичного розвитку націй і народів, до вузькопрофесійних сфер, світоглядних орієнтацій тощо.

Для України, яка пережила тривалий історичний період бездержавності та попри все має добрі традиції в розвитку музейної справи, музеї $є$ вагомим, дуже креативним і творчим доповненням до ресурсного (навчально-виховного, дослідницького) потенціалу освіти. У контексті освітніх реформ нагального вирішення потребує завдання щодо створення політико-правових, організаційно-педагогічних умов доступу до культури. Громадянськість, патріотичність, національна ідентичність, українськість, європейськість - якісні характеристики, цінності, які слід виховувати й утверджувати в свідомості, переконаннях, поведінкових нормах суспільства. Чимало законодавчих актів, указів Президента України спрямовані на реалізацію цих завдань, упровадження ціннісних орієнтирів у зміст навчальних і виховних програм. У цьому контексті особливо важливого значення набуває використання у педагогічній практиці виховного (державотворчого, націєтворчого, професійного, громадянського, естетичного, морального) потенціалу більшості музеїв. Цілий ряд музеїв різних профрілів (історичні, літературні, краєзнавчі, мистецькі, музичні), художні галереї і виставки містять багато нової інформації про видатних особистостей України, які були і залишаються гідним прикладом для наслідування сучасного і майбутніх поколінь.

На нашу думку, музейні експонати, предмети, матеріали сприяють вихованню дітей, молоді та дорослих на засадах україноцентризму, загальнолюдськості - ціннісних принципів, що визначають стратегію формування нації. Часто, пізнаючи у багатоаспектному вимірі ту чи іншу 
знакову постать, усвідомлюємо, наскільки необхідними є сутнісній дидактичні технології, що опираються на приклади життєдіяльності тих чи інших особистостей. Підтвердженням актуальності цього підходу слугують приклади, які впродовж останнього десятиліття мали місце на рівні освітньої, культурної політики держави. Прикро, але фактом залишається те, що серед наслідків, зумовлених зміною політичної кон'юктури, завжди була зміна ціннісних ідеалів.

Крізь призму життєдіяльності тієї чи іншої особистості, яка представляє певний історичний період розвитку, пізнається не просто своєрідність конкретної суспільної доби, але й формується відповідне емоційно-ціннісне ставлення до Людини, народу, країни, культури, духовних сенсів. На прикладах життя славетних українців пишеться жива історія нації і держави, виховується почуття особистої, національної гідності й гордості, патріотизм, формується україноцентричний світогляд. Навіть окремі сторінки творчості, життєві епізоди можуть закладати у процес виховання нації значний потенціал продуктивного впливу. Так, у Музично-меморіальному музеї Соломії Крушельницької (м. Львів) у 2018 р. була представлена експозиція, приурочена до події дев'яностолітньої давності (1928р.) - велике концертне турне видатної співачки містами США і Канади. Коротка життєва мить творчості. Без сумніву, кожен, осмислюючи світопочуттєві горизонти великої майстрині оперної сцени, може осягнути національно-духовне багатство у пізнавальному, естетичновиховному, історичному та інших контекстах.

Акцентуємо увагу на доцільності пошуку для педагогіки, культури, історії тих граней, що передусім характеризують національнодержавницьке буття народу, його свідомість, культуру світогляду, ціннісні орієнтири. I коли саме під таким кутом поглядів і ставлень дається оцінка ролі Соломії Крушельницької в історії українства, аналізується модель «Крушельницька - Україна - Світ», то народжуються дещо інші міркування, підходи, ідеї. Відчутним стає «борг» народу і держави перед пам'яттю знакових співвітчизників, що своїм талантом і служінню Україні творили національну славу в світовому просторі. Завдяки таким Особистостям Світ пізнавав і знав Україну, оскільки саме завдяки діалогу культур він виживає і морально здатен прогресувати. Культура як цінність $є$ візитівкою кожної нації, її обличчям. Втрата культурності - деградація народності. Тому «золотий фонд» українського народу має не тільки оберігатися, але й всіляко пошановуватися, стаючи опертям для націє-творчості, зміцнення державності.

Концепція мистецької освіти України має ввібрати в себе творчість, естетичні й етичні ідеї, націо-державотворчі потенціали, цінності й талант великих українців сущих в Україні і поза межами материзни. Адже народ, який зумів за всю свою історію сотворити понад 800 тисяч творів пісенної культури, що вдвічі більше, аніж мають усі країни ЄС, не може виховуватися на чужих цінностях, забувши про свої. Тому історія «відкриття Америки» Соломією Крушельницькою $є$ підтвердженням 
«конвертованості» української національної культури за кордоном, її універсальності й загальнолюдськості, глибокої традиції і народності. В умовах бездержавності Крушельницька гідно представляла Україну через українську пісню, високий талант оперної співачки. Європа, Південна і Північна Америка були зачаровані її сильним й елегантним співом.

Музей створює інтелектуально-духовний простір, який наділений значно більшими можливостями сформувати цілісну картину професійної, духовної, етичної, ментальної характеристики особистості, аніж простір навчального закладу. Тому часто об'єднавши зусилля педагогів і музейників, можна оптимально розкрити, вивівши дидактично правильно місце в навчально-виховному процесі. Для суспільства, яке продовжує жити в умовах гострої соціально-економічної і гуманітарної кризи, а тим паче війни, конфліктів, маючи розбіжність поглядів і оцінок щодо багатьох історичних явищ, конче потрібні об'єднуючі ідеали.

Музейний простір значно розширює й збагачує інтелектуальний потенціал людини, пізнавально-виховний потенціал культури, освіти тощо. Передусім можна констатувати, що можливість проведення в музейних установах різнотипових уроків, лекцій, презентацій, публічних заходів, у яких беруть активну участь відвідувачі (педагоги, учні, студенти, батьки, громадські і професійні діячі), підвищує рівень навчально-виховного процесу, удосконалює через неформальні форми і методи якість сприйняття заданої теми. По-друге, посилюється емоційно-почуттєва й мотиваційна сфера, критичне мислення, активна позиція у ставленні до «когось» чи «чогось». По-третє, у музейно-педагогічному процесі важливо, щоби кількість, особливо якість, новизна музейних предметів, експонати та експозиції містили багатшу за змістом і формами інформацію, аніж та, що $є$ в наявності школи, коледжу, гімназії чи іншого закладу. По-четверте, результати, успіх у досягненні певних дидактичних, виховних, дослідницько-пізнавальних цілей залежатимуть не тільки від якісних характеристик музейних експонатів, підібраних відповідно мети і поставлених завдань. Тут особлива роль також належить якості культурноосвітніх аспектів музейної комунікації. Тому оптимальний доступ до культурно-історичного матеріалу, ефект педагогічної дії і взаємодії, діалогічність процесу, нарешті, вмотивованість і зацікавленість проблемою та предметом вивчення, розгляду, визначається, насамперед, рівнем педагогічно-психологічної культури музеєзнавців і культурологічною, психологічною підготовкою вчителя, вихователя, викладача. По-п'яте, варто визнати як об'єктивну реальність, що в музеєзнавстві завжди відображається вплив (політичний, ідеологічний, культурно-історичний, ментальний, соціальний), а тому часто одні й ті ж самі факти, явища, події, особистості оцінюються й трактуються по-різному, містять полярні виміри.

Закономірно, що музейна педагогіка не може знаходитися осторонь зазначених вище впливів. П̈ї функціональний зміст $\epsilon$ взаємозалежним від суспільних процесів, освітніх, культурних і політичних стратегій держави в конкретному історичному періоді. Суспільні й 
цивілізаційні, національні й глобальні запити, інтереси Людини потребують адекватної реакції музейників і педагогів, які мають безперервно навчатись й удосконалюватись, духовно, інтелектуально, морально. Оскільки, як писав фрілософ, психолог Т. Карлейль, все пильнується і діяльно твориться, бо немає предмету, що знаходиться в бездіяльності (Карлейль, 1906).

Висновки. Отже, не тільки нинішня політична, соціальна, духовна, безпекова, міжнародна ситуація актуалізує плекання цінностей української ідентичності, ствердження єдиної ідеологічної концепції щодо впровадження національної ідеї. До таких підходів спонукає необхідність реалізації положень багатьох нормативних, законодавчих документів, зокрема Конституції України, а також рішень державного рівня щодо агресії Росії. По-друге, значущість ознайомлення з музейними матеріалами такого змісту українознавства полягає в тому, що національна культура, історична національна пам'ять, рідна (державна) мова і тоді, і зараз розглядаються як вищі духовні цінності нації, без яких немислима націєдержавотворчість, консолідація народу, розвиток громадянського суспільства.

По-третє, поява на загальноукраїнському, регіональному чи місцевому рівнях подібних музейних розвідок-експозицій становить далеко не відомчий інтерес. Очевидно, що вмотивований інтерес властивий як музейним установам, так і закладам освіти (школа, гімназія, коледж, інститут, університет, академія). Адже культурна й освітня інституція за метою, завданнями своєї діяльності мають спільну філософію виховання громадянськості й патріотизму, формування національної свідомості, державної і особистої гідності, пізнання культурної спадщини, надбань науки, розвиток критичного мислення, творчих здібностей, громадянської активної позиції. Саме тому музейні розробки, матеріали пошуково-дослідницького характеру - унікальний навчально-виховний і науково-творчий потенціал для удосконалення освітнього процесу. Почетверте, музейна педагогіка володіє оптимальними можливостями для формування у молоді таких необхідних якостей, як критичність, активність, креативність, зважаючи на особистісно-емоційне сприйняття.

Перспективними напрямами подальших досліджень вважаємо розроблення технологічних засад використання потенціалу музейної педагогіки у сфері педагогічної освіти та освіти дорослих.

\section{Список використаних джерел}

Валенкевич, О. В. (2015). Становлення та розвиток музейної педагогіки. Проблеми освіти: науково-методичний збірник. Інститут інноваційних технологій і змісту освіти МОН України. 85. 48-52.

Гайда, Л. А. (2016). Музейна педагогіка як навчальна дисципліна. Музейна педагогіка - проблеми, сьогодення, перспективи. Матеріали Четвертої науково-практичної конференції (27-28 вересня 2016 р.). Національний Києво-Печерський історико-культурний заповідник. 35-38.

Грищенко, Ю. В. (2016). Популяризація спадщини видатних українських 
педагогів-музикантів засобами музейної педагогіки. Музейна педагогіка - проблеми, сьогодення, перспективи. Матеріали Четвертої науково-практичної конференції (27-28 вересня 2016 p.). 43-44.

Дробна, Н. (2011). Технології музейної педагогіки. Директор школи. (Шкільний світ). 9. 24-25.

Карлейль, Т. (1906) Этика жизни. Трудиться и не унывать! Перев. Е. Синерукой. [Електронний ресурc]. URL: http://az.lib.ru/k/karlejlx_t/text_0040.shtml

Прийма С. М., Іванова Н. М., Аніщенко О. В. (2017). Музейна педагогіка: потенціал для розвитку неформальної освіти на Мелітопольщині. Педагогічна майстерність як система профресійних і мистецьких компетентностей : зб. матеріалів XIV Міжнар. педагогічномистецьких читань пам'яті профь. О. П. Рудницької [гол. ред.: Г. І. Сотська]. К. : Талком, 8 (12), 243-245.

Цибко, С. (2011) Музейна педагогіка в навчально-виховному процесі. Директор школи. 3. 91-93.

Черничко, А. (2014) Унікальна методика музейної педагогіки. Сучасна школа України. 12. 67-87.

\section{References (translated and transliterated)}

Valenkevych, O. V. (2015) Establishment and development of museum pedagogy. Problemy osvity: naukovo-metodichni zbirnik. Instytut innovacijnyh tehnologij i zmistu osvity MON Ukrayiny. 85. 48-52. (in Ukrainian)

Gajda, L. A. (2016) Museum pedagogy as a teaching discipline. Muzejna pedagogika - problemy, sogodennya, perspektyvy. Materialy Chetvertoyi naukovopraktychnoyi konferenciyi (27-28 veresnya, 2016). 35-38. (in Ukrainian)

Gryshhenko, Y. V. (2016) Promoting the Heritage of Prominent Ukrainian Music Teachers by Museum Pedagogy. Muzejna pedagogika - problemy, sogodennya, perspektyvy. Materialy Chetvertoyi naukovo-praktychnoyi konferenciyi (27-28 veresnya 2016 r.). 43-44. (in Ukrainian)

Drobna, N. (2011) Technologies of museum pedagogy. Dyrektor shkoly. (Shkilnyj svit). 9. 24-25. (in Ukrainian)

Karleyl, T. (1906) Etika zhizni. Truditsya i ne unyivat! Perev. E. Sinerukoy. [Elektronnyiy resurs]. URL: http://az.lib.ru/k/karlejlx_t/text_0040.shtml (in Russian)

Pryima, S., Ivanova N. Anishchenko, O. (2017). Museum pedagogy: potential for development of non-formal education in Melitopol. Pedagoglchna maysternlst yak sistema profeslynih I mistetskih kompetentnostey : zb. materlallv XIV MIzhnar. pedagoglchno-mistetskih chitan pam'yatl prof. O. P. RudnitskoYi [gol. red.: G.I. Sotska]. K : Talkom, 8 (12), 243-245. (in Ukrainian)

Cybko, S. (2011) Museum pedagogy in the educational process. Dyrektor shkoly. 3, 91-93. (in Ukrainian)

Chernychko, A. (2014) Unique methodology of museum pedagogy. Suchasna shkola Ukrayiny. 12. 67-87. (in Ukrainian) 